\title{
ING2 wt Allele
}

National Cancer Institute

\section{Source}

National Cancer Institute. ING2 wt Allele. NCI Thesaurus. Code C77206.

Human ING2 wild-type allele is located in the vicinity of $4 \mathrm{q} 35.1$ and is approximately $6 \mathrm{~kb}$ in length. This allele, which encodes inhibitor of growth protein 2 , is involved in the regulation of apoptosis and protein acetylation. Aberrant expression of the gene is associated with colon tumors. 